\title{
ANTIOXIDANT ACTIVITY, TANNIN CONTENT AND DIETARY FIBER FROM COFFEE HUSK EXTRACT AND POTENTIAL FOR NUTRACEUTICAL
}

\author{
Anton Restu Prihadi ${ }^{1}$, Askal Maimulyanti ${ }^{2, *}$, Bella Mellisani ${ }^{2}$ \\ and Nurhasanah ${ }^{1}$ \\ ${ }^{1}$ Department of Quality Assurance of Food Industry, Politeknik AKA Bogor, Indonesia \\ ${ }^{2}$ Department of Analytical Chemistry, Politeknik AKA Bogor, Indonesia \\ *E-mail: askal_m@yahoo.com
}

\begin{abstract}
The coffee processing industry still produces a lot of solid waste that has not been utilized optimally. The use of coffee husk waste is only as animal feed and fertilizer. While, the compound content in coffee husk waste contains high-fiber and it is indicated to be used as an antioxidant, antimicrobial, anti-allergic, and anti-hypertensive. The sample of coffee husk waste was mashed into a homogeneous powder then the analysis was carried out using volumetric, gravimetric, and UV-Vis spectrophotometry methods. Here, we report the antioxidant activity, tannin content, total dietary fiber and potential nutraceutical from the coffee husk. Antioxidant activity of coffee husk was very strong $\left(\mathrm{IC}_{50}=20 \mathrm{ppm}\right)$ and tannin content was $10 \%$. Hence, the coffee husk can be potential as raw material for making nutraceutical that used for the treatment of diseases caused by free radical exposure. The total dietary fiber of coffee husk was obtained by $34 \%$. Thus, coffee husk waste also can be utilized as the prevention of digestive diseases.
\end{abstract}

Keywords: Coffee Husk, Extract, Antioxidant, Tannin, Dietary Fiber

(C) RASĀYAN. All rights reserved

\section{INTRODUCTION}

Waste produced from the process of separating coffee from the seeds (pulping process) in the biomass form is very abundant. It is currently used as animal feed, compost, and raw material for making bioethanol. Coffee husk is outer skin that has a hard surface and has been separated from the husk (coffee silverskin). Residues from the coffee industry process can be used as a flavour, biosorbents, emulsions, fibers, soft drinks, energy drinks, and cosmetics). This is due to coffee husk containing caffeine, tannin, polyphenol, pectin, monosaccharide, and disaccharide compounds ${ }^{1}$.

The coffee husk contains various phenolic and caffeine compounds with phytochemical bioactivity in food mixtures which have potential properties to maintain human health. Phenolic and flavonoids have the potential as antioxidants, antimicrobial, anti-allergic, and anti-hypertensive activities ${ }^{2}$. Polyphenol compounds in coffee husk have an antioxidant activity of $13 \mathrm{mg} / \mathrm{g}^{3}$. The antioxidant is an important role in human health because the antioxidant can capture free radicals ${ }^{4,5}$.

Also, coffee husk waste is thought to contain high fiber, probiotics, and antioxidants. It is usually used for food formulations that contain low-calorie sugar. Coffee husk is known to improve sugar level and stimulate insulin secretion ${ }^{6}$. With the increase in obesity in the world, cardiovascular disease, cancer, metabolic syndrome, and diabetes, some research is now directed at novel discoveries in food products and supplemental drugs to treat various diseases. Based on research in Spain, the nutrients composition contained in the coffee husk is applied to drinks that can treat various diseases ${ }^{7}$. Polyphenol and caffeine compounds in the coffee husk can be analyzed by high-performance liquid chromatography/mass spectrometry (LCMS) ${ }^{8}$.

The potential use of coffee husk as a nutraceutical through analysis of antioxidant activity, tannin levels, and dietary fiber. Coffee husk samples were mashed into homogeneous powder, then the analysis was

Rasayan J. Chem., 13(2), 955-959(2020)

http://dx.doi.org/10.31788/RJC.2020.1325613

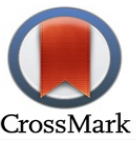


RASĀYAN J. Chem.

Vol. 13 | No. 2 |955 - 959| April - June | 2020

carried out using volumetric, gravimetric, and UV-Vis spectrophotometry methods. This study aims to determine antioxidant activity, tannin levels, and dietary fiber in samples of coffee husk. It is a process to present the nutraceutical composition of coffee husk to overcome human health problems. It included preparation of coffee husk samples and continued analysis of dietary fiber levels using the gravimetric method, tannin levels using the volumetric method, and antioxidant activity by UV-Vis spectrophotometry.

\section{Material and Methods}

\section{EXPERIMENTAL}

Arabica (Coffea arabica) coffee husks were obtained directly from coffee collectors in Pangalengan, West Java. Coffee husks were washed several times with distilled water. Then, they were dried using an oven equipped with blower at a temperature of $50^{\circ} \mathrm{C}$. The dried coffee husks were crushed using crusher until the particle size was passed through 18 mesh sieve $( \pm 1 \mathrm{~mm})$.

\section{Tannin Content Analysis}

The sample was weighed $2.0 \mathrm{~g}$ and entered to beaker glass. Then, $50 \mathrm{~mL}$ of boiling water was added to the beaker glass. The sample solution was left for $20 \mathrm{~min}$ and entered into a $100 \mathrm{~mL}$ volumetric flask. It was filtered into a dry beaker glass. A $5 \mathrm{~mL}$ filtrate was entered to erlenmeyer and added $75 \mathrm{~mL}$ distilled water, $5 \mathrm{~mL}$ indigo carmine. $\mathrm{KMnO}_{4}$ with the concentration of $0.1 \mathrm{~N}$ was used to titration of the solution until the color changed from blue to yellow. The volume of titrant was recorded as A. Then, a $10 \mathrm{~mL}$ filtrate was added $10 \mathrm{~mL} \mathrm{NaCl}, 5 \mathrm{~mL}$ sample (filtrate) was added of $10 \mathrm{~mL} \mathrm{NaCl}, 5 \mathrm{~mL}$ gelatin and $2 \mathrm{~g}$ kaolin. It was stirred to reach homogeneous and filtered slurry from the filtrate. $5 \mathrm{~mL}$ filtrated was added $75 \mathrm{~mL}$ distilled water and $5 \mathrm{~mL}$ indigo carmine. It was titrated with $0.1 \mathrm{~N} \mathrm{KMnO}_{4}$ and the color was changed from blue to yellow. The volume of titrant was recorded as B. The result was calculated using this equation:

$$
\operatorname{Tannin}(\%)=\frac{(\mathrm{A}-\mathrm{B}) \times \mathrm{N} \mathrm{KMnO} 4 \times 42 \times \frac{100}{5} \times 10^{-3}}{\text { sample }(\mathrm{g})} \times 100 \%
$$

\section{Antioxidant Activity}

The solution of DPPH $0.4 \mathrm{mM}$ was made by weighing $3.98 \mathrm{mg}$ DPPH and dissolved into a $25 \mathrm{~mL}$ volumetric flask with methanol ${ }^{9}$. A standard solution of $500 \mathrm{ppm}$ was made by weighing $5 \mathrm{mg}$ of sample and dissolved in a $10 \mathrm{~mL}$ volumetric flask with distilled water. The serial samples were made with a concentration of $1,3,5,7$, and $10 \mathrm{ppm}$ by pipetting the standard solution of $10,30,50,70$, and $100 \mu \mathrm{L}$. Then, each serial was added $1 \mathrm{~mL}$ DPPH and methanol up to the volume of $5 \mathrm{~mL}$, left for $30 \mathrm{~min}$ and measured the absorbance at a wavelength of $517 \mathrm{~nm}$. Percent of free radicals reduction was determined with the following equation :

$$
\% \text { Inhibition }=\frac{\left(A_{0}-A_{T}\right)}{A_{0}} \times 100 \%
$$

Where Ao is the absorbance of sample solution added $0.1 \mathrm{mM}$ DPPH solution. At is an absorbance control solution

\section{Total Dietary Fiber}

The sample was weighed $0.5 \mathrm{~g}$ and added $40 \mathrm{~mL}$ MES-TRIS (Buffer $\mathrm{pH} 8$,2). It was stirred to reach homogeneous. The $50 \mu \mathrm{L}$ of $\alpha$-amylase was added to the solution and was stored in $95-110^{\circ} \mathrm{C}$ for $35 \mathrm{~min}$. It was left to $60^{\circ} \mathrm{C}$ and beaker glass was rinsed $10 \mathrm{~mL}$ of distilled water. After that, it was added $100 \mu \mathrm{L}$ protease and incubated at the temperature of $60{ }^{\circ} \mathrm{C}$ for $30 \mathrm{~min}$. $\mathrm{HCl}$ was used to make $\mathrm{pH} 4.5$ of the solution. The volume of $200 \mu \mathrm{L}$ amyloglucosidase was added and the solution was incubated for 30 minutes at the temperature of $60{ }^{\circ} \mathrm{C}$. The solution was precipitated using $225 \mathrm{~mL}$ ethanol $95 \%$ at $60{ }^{\circ} \mathrm{C}$. The precipitate was left for an hour at room temperature. It was filtered with filter paper no. 42 which has known the weight. The precipitate was dried in the oven at $70{ }^{\circ} \mathrm{C}$ or $105^{\circ} \mathrm{C}$. The residue obtained consists of two parts, namely protein, and ash which was a total dietary fiber. 
RASĀYAN J. Chem.

Vol. 13 | No. 2 |955 - 959| April - June | 2020

$$
\operatorname{Tannin}(\%)=\frac{(\mathrm{A}-\mathrm{B}) \times \mathrm{N} \mathrm{KMnO} 4 \times 42 \times \frac{100}{5} \times 10^{-3}}{\text { sample }(\mathrm{g})} \times 100 \%
$$

\section{RESULTS AND DISCUSSION}

The results of tannin content in coffee husk waste using the volumetric analysis method were shown in Table-1.

\begin{tabular}{c|c} 
Table-1: Tannin Content in Coffee Husk Waste \\
\hline Analysis & Content $(\%)$ \\
\hline Tannin & 10.05 \\
\hline
\end{tabular}

Tannin content found in coffee husk waste was $10.05 \%$. Tannin was generally obtained from deciduous bark and certain types of tree bark because coniferous trees only have a small amount of tannin. Tannin contained in dry bark of several species varies from $2-40 \%{ }^{10}$. Tannin was often used as an active antioxidant and antimicrobial substances. Therefore, coffee husk waste can be used to isolate the tannin. It also can be applied as a nutraceutical which provides benefits for the prevention and treatment of microbial diseases. Hence, tannin can be obtained from the coffee industry waste and no longer need to be obtained by cutting down wood in the forest. Also, tannin content in coffee husk waste was equivalent to the tannin content found in tea leaves and coffee beans. Tannins are the complex compounds contained polyphenols with high biological activity ${ }^{11}$. The results tannin content indicates the potential of coffee husk waste as an antioxidant. Therefore, coffee husk waste was determined the antioxidant activity quantitatively. The results were shown in Table-2.

Table-2: Antioxidant Activity in Coffee Husk

\begin{tabular}{c|c|c}
\hline Concentration $(\mathrm{ppm})$ & Absorbance & Inhibition (\%) \\
\hline 0 & 0.8784 & 0 \\
\hline 1 & 0.8181 & 6.86 \\
\hline 3 & 0.8094 & 7.85 \\
\hline 5 & 0.7839 & 10.76 \\
\hline 7 & 0.7272 & 17.21 \\
\hline 10 & 0.6602 & 24.84 \\
\hline
\end{tabular}

Table-2 shows the inhibition of free radical activity using the DPPH method including the percent inhibition of coffee husk extract. This shows that the higher the coffee husk waste concentration, the greater the antioxidant activity. Therefore, if it was observed the correlation between the coffee husk waste concentration analyzed on its antioxidant activity, a linear relation was obtained. The correlation between sample concentration and inhibition percentage was shown in Fig.-1.

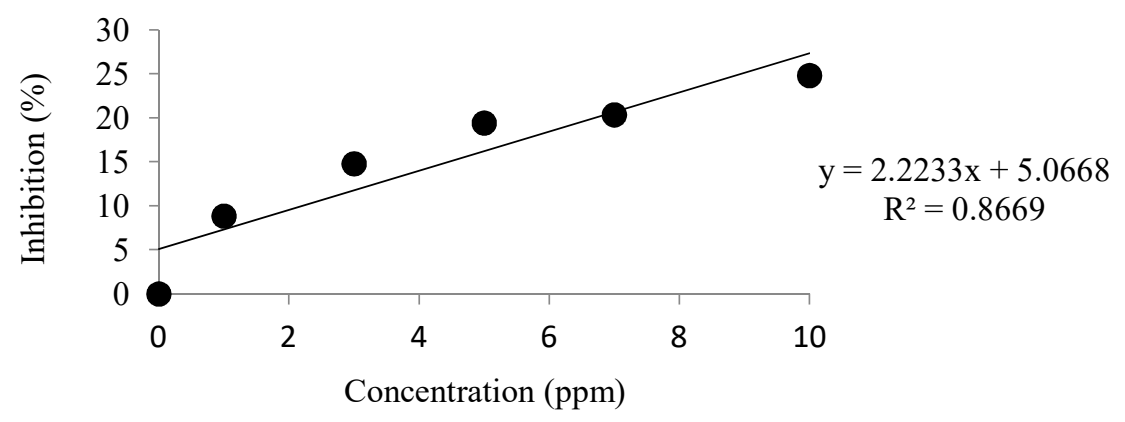

Fig.-1: Correlation of Coffee Husk Concentration to Antioxidant Activity 
The antioxidant activity of coffee husk waste was determined quantitatively. The linear regression was obtained in the form of $\mathrm{y}=\mathrm{a}+\mathrm{bx}$ used to find the $\mathrm{IC}_{50}$ value (inhibitor concentration $50 \%$ ) of each sample by indicating the $\mathrm{Y}$ value of 50 and the $\mathrm{x}$ value to be determined from IC50. The $\mathrm{IC}_{50}$ value indicates the amount of solution concentration needed to reduce DPPH free radicals of $50 \%$. The calculation results of the linear regression were obtained $\mathrm{y}=2.2233 \mathrm{x}+5.0668$, so the $\mathrm{IC}_{50}$ value was 20 $\mathrm{ppm}$. These show that the coffee husk waste has the potential to inhibit free radicals of $50 \%$ classified very strong. The classification of antioxidants was divided into 5 classes namely very strong $(<50 \mathrm{ppm})$, strong (50-100 ppm), medium (100-150 ppm), weak (150-200 ppm) and very weak (>200 ppm) ${ }^{12}$. Cancer starts from a genetic mutation that causes damage to DNA. Hence, antioxidant compounds were studied from food, drinks, and herbs related to their activities in genetic damage prevention. Another potential nutraceutical determined from the coffee husk waste was total dietary fiber. Total dietary fiber results in coffee husk were shown in Table-3.

Table-3: Total Dietary Fiber in Coffee Husk

\begin{tabular}{c|c|c|c|c|c}
\hline No. & Sample $(\mathrm{g})$ & $\begin{array}{c}\text { Average Sample } \\
(\mathrm{g})\end{array}$ & Ash $(\mathrm{g})$ & Protein $(\mathrm{g})$ & $\begin{array}{c}\text { Total Dietary } \\
\text { Fiber }(\%)\end{array}$ \\
\hline 1 & 0.5040 & 0.3061 & 0.0843 & 0.0496 & 34.14 \\
\hline 2 & 0.5045 & & & & \\
\hline 3 & 0.5060 & 0.3061 & 0.0841 & 0.0496 & 34.16 \\
\hline 4 & 0.5028 & & & & \\
\hline
\end{tabular}

Total dietary fiber in coffee husk was $34 \%$ that higher than total dietary fiber in a grain of rice which is $0.94 \%$. Dietary fiber is a carbohydrate class compounds that do not undergo the digestion and absorption process. It also did not undergo fermentation by microbes in the human intestinal tract. Nutraceutical intake with high levels of dietary fiber has the efficacy to maintain human health from the risk of cardiovascular disease, hypertension, diabetes, obesity, and digestive tract diseases. Therefore, women with an energy requirement of $2000 \mathrm{kcal} /$ day were recommended for a daily intake of $28 \mathrm{~g} /$ day of dietary fiber. Whereas men with a calorie requirement of $2600 \mathrm{kcal} /$ day were recommended dietary fiber intake of $36 \mathrm{~g} /$ day.

\section{CONCLUSION}

The coffee husk waste has potential as raw material for making nutraceutical that used for the treatment of diseases caused by free radical exposure. This was caused by tannin content as much as $10 \%$ and very strong antioxidant activity $\left(\mathrm{IC}_{50}=20 \mathrm{ppm}\right)$. On the other hand, the coffee husk waste can be utilized as prevention of digestive diseases, because the total dietary fiber was quite high, which was equal to $34 \%$.

\section{ACKNOWLEDGMENT}

We would like to thanks Politeknik AKA Bogor to provide the financial of this research for project number of 110/POLTEK.AKA/5/2018.

\section{REFERENCES}

1. B. Janissen and T. Huynh. Resources, Conservation and Recycling, 128, 110(2018), DOI: 10.1016/j.resconrec.2017.10.001

2. F. Sahidi, P.K. Janitha and P.D. Wanasundara, Critical Reviewers in Food Science and Nutrition, 32(1), 67(1992), DOI:10.1080/10408399209527581

3. E.M.S. Machado, R.M. Rodriquez-Jasso, J.A. Teixeira and S.I. Mussatto. Biochemical Engineering Journal, 60, 87(2012), DOI:10.1016/j.bej.2011.10.007

4. Supomo, E.S. Syamsul, A. Apriliana, C. Saleh, Erwin and D. Lestari, Rasayan Journal of Chemistry, 12(3), 1340(2019), DOI:10.31788/RJC.2019.1235264

5. T. Okselni, A. Santoni, A. Dharma and M. Efdi, Rasayan Journal of Chemistry, 11(3), 1211(2018), DOI: $10.31788 /$ RJC.2018.1133058

6. B.F. Gomez, S. Ramos, L. Goya, M.D. Musa, M.D., Castillo and M.A. Martin. Food Research International, 89(2), 1015 (2016), DOI:10.1016/j.foodres.2016.03.006 
RASĀYAN J. Chem.

Vol. 13 | No. 2 |955 - 959| April - June | 2020

7. N.M. Saez, M. Ullate, M.A.M. Cabrejas, P. Martorell, S. Genoves, D. Ramon and M.D., Castillo, Food Chemistry, 150, 227 (2014), DOI:10.1016/j.foodchem.2013.10.100

8. L. Bresciani, L. Calani, R. Bruni, F. Bighenti and D.P. Rio. Food Research International, 61,196 (2014), DOI:10.1016/j.foodres.2013.10.047

9. O. Atolani, C.B. Adeosun, A.P. Oluyori and J. Olota. Rasayan Journal of Chemistry, 12(3), 1052 (2019), DOI:10.31788/RJC.2019.1235122

10. H.L. Hergert. American Chemical Society. 155(1989), DOI: 10.1021/bk-1989-0385.ch012

11. H. Savolainen. Journal of Applied Toxicology. 12(3), 191 (1992), DOI:10.1002/jat.2550120307

12. M.R. Szabo, C. Iditoiu, D. Chambre and A.X Lupea. Chemical Papers, 61(3), 214 (2007), DOI: 10.2478/s11696-007-0022-7

[RJC-5613/2019] 